\title{
RANCANG BANGUN ALAT PERAGA FISIKA BERBASIS ARDUINO (Studi Kasus Gerak Jatuh Bebas)
}

\author{
Migdes C. Kause ${ }^{1}$ dan Infianto Boimau ${ }^{2}$ \\ Program Studi Pendidikan Fisika, Sekolah Tinggi Keguruan dan Ilmu Pendidikan Soe \\ Jl. Badak No.5A Lokasi 2 SMK N 1 SoE, TTS \\ email: stafinfiantoboimau@stkip.ac.id
}

\begin{abstract}
Abstrak - Telah dilakukan rancang bangun alat peraga fisika pada kasus gerak jatuh bebas berbasis Arduino. Alat peraga yang telah dikembangkan bertujuan untuk memvisualisasikan fenomena gerak jatuh bebas dan mengukur percepatan gravitasi bumi dan membuktikan konsep-onsep gerak jatuh bebas. Rancang bangun alat peraga menggunakan komponen elektronik seperti Arduino, sensor inframerah, sensor ultrasonik, push button, LCD, relay, dan LED sebagai komponen utama perangkat keras (hardware). Perangkat lunak (software) yang digunakan dalam mengembangkan alat peraga ini memanfaatkan compiler IDE Arduino berbasis bahasa C\#. Besaran fisis yang diukur menggunakan alat peraga yang dikembangkan dalam penelitian ini adalah ketinggian benda dan waktu tempuh benda. Hasil pengujian kinerja alat peraga yang dikembangkan menunjukkan bahwa alat peraga mampu memvisualisasikan fenomena gerak jatuh bebas, mengukur percepatan gravitasi bumi dengan nilai rata-rata sebesar $10,2 \mathrm{~m} / \mathrm{s}^{2}$, dan membuktikan konsep-konsep dalam gerak jatuh bebas.
\end{abstract}

\section{Kata kunci : Alat Peraga, Arduino, Gerak Jatuh Bebas}

\begin{abstract}
There is an effort to design learning media for teaching physics on free fall based on Arduino. The learning media designed is aimed at visualizing free fall phenomena, measuring earth gravitation speed, and proofing the concepts of free fall. Designing learning media using electronic components such as Arduino, infrared sensor, ultrasonic sensor, pushbutton, LCD, relay, and LED as the main components hardware devices. Software devices which are used to improve this learning media were IDE Arduino Compiler C\# language base. Physics quantity which is measured using the designed learning media in this study were the object's height and the needed time. The test result of the designed learning media this study showed that this learning media could visualize free fall phenomena, measure the earth gravitation speed with the average score was $10,2 \mathrm{~m} / \mathrm{s}^{2}$, and proofing free fall concepts.
\end{abstract}

Keywords： Learning Media, Arduino, Free Fall

\section{PENDAHULUAN}

Ilmu fisika merupakan ilmu yang menjelaskan berbagai fenomena fisis secara abstrak sehingga dalam penyampaian berbagai konsep fisika dalam proses pembelajaran tidak hanya semata transaksi informasi saja dari pengajar kepada peserta didik. Pemahaman yang mendalam diperlukan untuk memahami dengan benar konsep-konsep yang dipelajari dan hal ini hanya dapat terjadi melalui latihan ketrampilan dan pengalaman. Jika hal ini dapat dilakukan dalam proses pembelajaran di kelas, maka anggapan tentang pelajaran fisika yang sulit dapat dihilangkan. Penyampaian pembelajaran fisika harus membawa peserta didik ke dalam kehidupan nyata, sebab dengan menggunakan situasi kehidupan nyata, peserta didik akan menemukan fisika lebih relevan sehingga membuat peserta didik lebih terlibat dan termotivasi dalam proses pembelajaran [1].
Rendahnya kemampuan peserta didik dalam memahami konsep-konsep yang abstrak dan kurang aktifnya peserta didik dalam proses pembelajaran memerlukan adanya solusi berupa media pembelajaran yang mampu meningkatkan motivasi dan prestasi belajar peserta didik. Media pembelajaran berperan penting untuk menciptakan proses pembelajaran yang optimal karena dapat meningkatkan interaksi antara guru dan peserta didik. Media pembelajaran berfungsi untuk memperjelas pesan agar tidak terlalu verbalitas mengatasi keterbatasan ruang, waktu, tenaga, dan daya indra, menimbulkan gairah belajar, memungkinkan peserta didik belajar sesuai bakat dan kemampuan, visual, auditori, dan kinestetiknya, dan memberikan ransangan dan presepsi yang sama [2].

Salah satu media pembelajaran yang efektif untuk menjelaskan konsep yang abstrak dan menarik minat belajar peserta didik dalam proses pembelajaran adalah alat 
peraga atau alat praktikum. Alat peraga merupakan media pembelajaran yang mengandung dan membawakan ciri-ciri dari konsep yang dipelajari [3]. Dalam proses pembelajaran alat peraga dapat memperjelas penyajian pesan dan informasi mengenai pelajaran fisika yang disampaikan oleh guru. Penggunaan alat peraga membantu mempermudah peserta didik memahami suatu konsep yang abstrak menjadi konkrit. Menurut kerucut pengalaman Dale dalam diketahui bahwa pengalaman belajar dengan cara melakukan akan menjelaskan suatu konsep secara nyata dan peserta didik akan mengingat $90 \%$ dari apa yang dilakukan [4]. Dengan demikian, proses pembelajaran akan lebih mudah dipahami apabila menggunakan media pembelajaran yang tepat.

Alat peraga pembelajaran adalah sarana komunikasi dan interaksi antara guru dengan siswa dalam proses pembelajaran [5]. Alat peraga menjadi media yang dapat digunakan untuk menyampaikan pesan sehingga dapat merangsang pikiran, perasaan, perhatian, dan minat peserta didik dalam proses pembelajaran. Pembelajaran dengan menggunakan alat peraga menjadi suatu rangkaian kegiatan untuk menyampaikan materi pelajaran yang bertujuan memberi kesempatan siswa untuk aktif belajar. Penerapan alat peraga memungkinkan siswa memperoleh pengetahuan dan mengembangkan keterampilan psikomotorik serta menumbuhkan kreatifitas siswa untuk memecahkan permasalahan yang dihadapi oleh peserta didik. Dengan demikian akan tercipta suatu proses pembelajaran yang berkualitas [3].

Alat peraga dapat dikembangkan secara inovatis dan kreatif sesuai dengan tujuan pembelajaran. Alat peraga dapat dikembangkan dengan memanfaatkan potensi dan sumber daya yang tersedia dan diperoleh dengan mudah. Alat peraga dapat dikembangkan dari bahan-bahan lokal sehingga alat peraga yang dihasilkan berbasis budaya lokal dan meningkatkan kebermanfaatan dari bahan-bahan lokal yang tersedia [6]. Alat peraga dapat pula dikembangkan dengan memanfaatkan sampah rumah tangga maupun sampah industri sehingga membantu mengurangi pemcemaran lingkungan [7].

Kemajuan ilmu pengetahuan dan teknologi menghasilkan berbagai perangkat elektronik yang membantu dalam pengembangan alat peraga. Beberapa perangkat elektronik penting dalam pengembangan media pembelajaran antara lain perangkat kontrol misalnya mikrokontroler, perangkat detektor atau sensor, perangkat display atau LCD, dan perangkat aktuator [8]. Dengan berbagai perangkat elektronik yang ada, rancang bangun alat peraga yang dihasilkan lebih efektif, efisisien dan memiliki akurasi hasil pengukuran dan visualisasi yang lebih baik. Alat peraga yang dihasilkan dengan berbagai komponen elektronik ini membuat peserta didik memiliki minat belajar yang besar dan meningkatkan pula kemampuan inovasi dan kreativitas siswa [9].

Tujuan penelitian ini adalah (1) mengembangkan alat peraga fisika dalam studi kasus gerak jatuh bebas berbasis Ardiuno, (2) menguji kinerja perangkat keras dan perangkat lunak dari alat peraga yang dikembangkan, (3) menguji kinerja alat peraga dalam mengukur ketinggian benda dan waktu tempuh yang digunakan dalam menganalisis dan membuktikan konsep-konsep gerak jatuh bebas, dan (4) menentukan nilai percepatan gravitasi bumi berdasarkan konsep gerak jatuh bebas dari alat peraga yang dikembangkankolom sehingga kolom kiri dan kanan sama panjang.

\section{METODE PERANCANGAN}

Rancang bangun alat peraga yang dikembangkan dalam penelitian ini terdiri dari empat tahap yaitu perancangan perangkat keras (hardware), perancangan perangkat lunak (software), perancangan sistem mekanik, dan pengujian kinerja alat peraga yang dikembangkan. Rancang bangun alat peraga ini digunakan untuk mengukur ketinggian benda dan waktu tempuh yang dibutuhkan benda ketika jatuh bebas dari ketinggian tertentu. Ketinggian benda diukur menggunakan sensor ultrasonik, sedangkan waktu tempuh dicacah menggunakan timer pada Arduino berdasarkan input dari tombol push button dan sensor inframerah.

Perancangan perangkat keras alat peraga yang dikembangkan terdiri dari tiga blok sistem yaitu input, proses, dan output. Input sistem perangkat keras terdiri dari sensor ultrasonik, sensor inframerah, dan tombol push button. Sistem pemrosesan data dikendalikan oleh Arduino yang berfungsi sebagai perangkat kontroler. Output sistem perangkat keras terdiri dari Liquid Crystal Display (LCD), Light Emitted Diode (LED), aktuator, dan kumparan terinduksi. Disamping itu, perancangan catu daya diperlukan untuk menyediakan arus bagi perangkatperangat elektronik. Diagram rancang bangun perangkat keras alat peraga yang dikembangkan ditunjukkan pada Gambar 1.

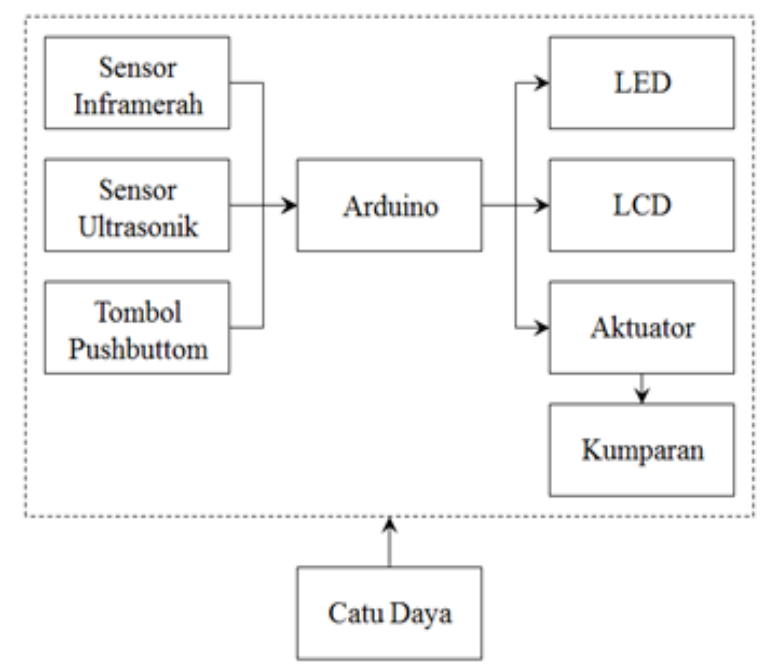

Gambar 1. Diagram perangkat keras alat peraga yang dikembangkan

Sistem perangkat keras yang ditunjukkan pada Gambar 1 memperlihatkan sensor ultrasonik berfungsi sebagai perangkat input untuk mengukur jarak, sensor inframerah berfungsi sebagai trigger untuk mencacah waktu tempuh benda, dan push button sebagai tombol kendali dalam melakukan pengukuran. Data-data input dari sensor maupun tombol push button akan diproses oleh Arduino 
sehingga diperoleh hasil pengukuran jarak dan waktu tempuh benda. Waktu yang ditempuh benda dicacah menggunakan fitur timer1 yang disediakan oleh Arduino sebagai stopwatch. Tipe Arduino yang digunakan dalam pengembangan alat peraga ini adalah Arduino Uno.

Hasil pengolahan data akan ditampilkan ke LCD agar dapat dibaca dengan mudah oleh pengguna (user). Hasil pengukuran yang ditampilkan pada LCD yaitu jarak/ ketinggian benda dan waktu tempuh benda selama mengalami gerak jatuh bebes. Sistem aktuator terdiri dari relay 12 VDC, transistor BD139, dan diode 1N4007 sebagai komponen utama untuk mengedalikan induksi magnet pada kumparan. Perubahan induksi dapat dikendalikan secara otomatis dari Arduino sehingga menyebabkan benda jatuh bebas ketika alat peraga digunakan untuk melaukan pengukuran. Sedangkan LED berfungsi sebagai indikator untuk memantau kinerja perangkat elektronik ketika dikendalikan oleh Arduino. LED yang digunakan dalam alat peraga ini sebagai indikator catu daya dan indikator kendali aktuator. Catudaya dirancang untuk menyediakan tegangan 12 VDC dan 5 VDC yang digunakan untuk menyuplai arus bagi semua perangkat elektronik. Rangkaian perangkat keras alat peraga yang dikembangkan ditunjukkan pada Gambar 2.

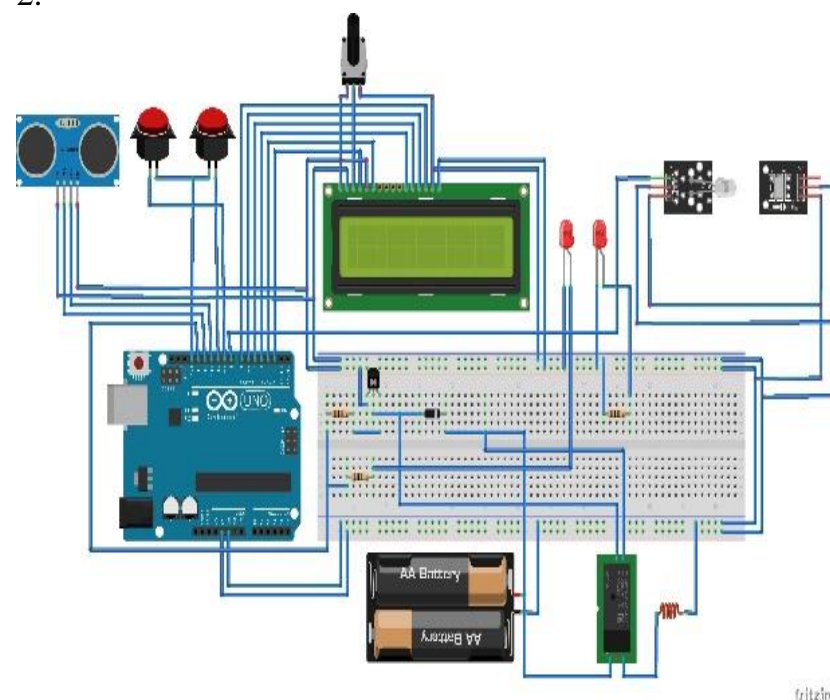

Gambar 2. Rangkaian perangkat keras (hardware) alat peraga dari alat peraga energi mekanik berbasis Arduino yang dikembangkan.

Perancangan perangkat lunak alat peraga menggunakan bahasa $\mathrm{C \#}$ dan compiler Integrated Development Environment (IDE) Arduino. Perancangan perangkat lunak terdiri dari beberapa blok utama yaitu deklarasi pustaka dan variabel, definisi pin-pin Arduino, setup pin-pin Arduino dan LCD, pembuatan fungsi timer dan interrupt timer, mengukur jarak, mengendalikan aktuator, mengukur waktu, dan menuliskan hasil pengukuran pada LCD. Flowchart perancangan perangkat lunak alat peraga yang dikembangkan ditunjukkan pada Gambar 3.

Perancangan perangkat mekanik berfungsi sebagai media visualisasi untuk memperagakan gerak jatuh bebas benda. Perancangan perangkat mekanik terdiri dari beberapa komponen utama, antara lain: lintasan, penyangga, waterpass, kotak sensor ultrasonik, kotak sensor inframerah, dan kotak elektronik. Dalam perancangan mekanik alat peraga tempat kedudukan benda yang dijatuhkan didesain menggunakan pengait agar dapat digeser up/down. Hal ini bertujuan agar diperoleh variasi ketinggian benda ketika dilakukan pengukuran.

Pengujian sistem perangkat elektronik dan kinerja alat peraga bertujuan mengetahui kelayakan dan keefektifan alat peraga dalam melakukan akuisisi data. Pengujian perangkat elektronik terdiri dari pengujian sensor inframerah, kalibrasi sensor ultrasonik, pengujian LCD, dan pengujian pengendalian aktuator. Perangkat-perangkat elektronik yang digunakan dalam alat peraga ini akan diuji kelayakannya masing-masing sebelum dirangkai menjadi sebuah alat peraga yang dapat digunakan untuk menganalisis konsep gerak jatuh bebas dan mengukur percepatan gravitasi bumi.

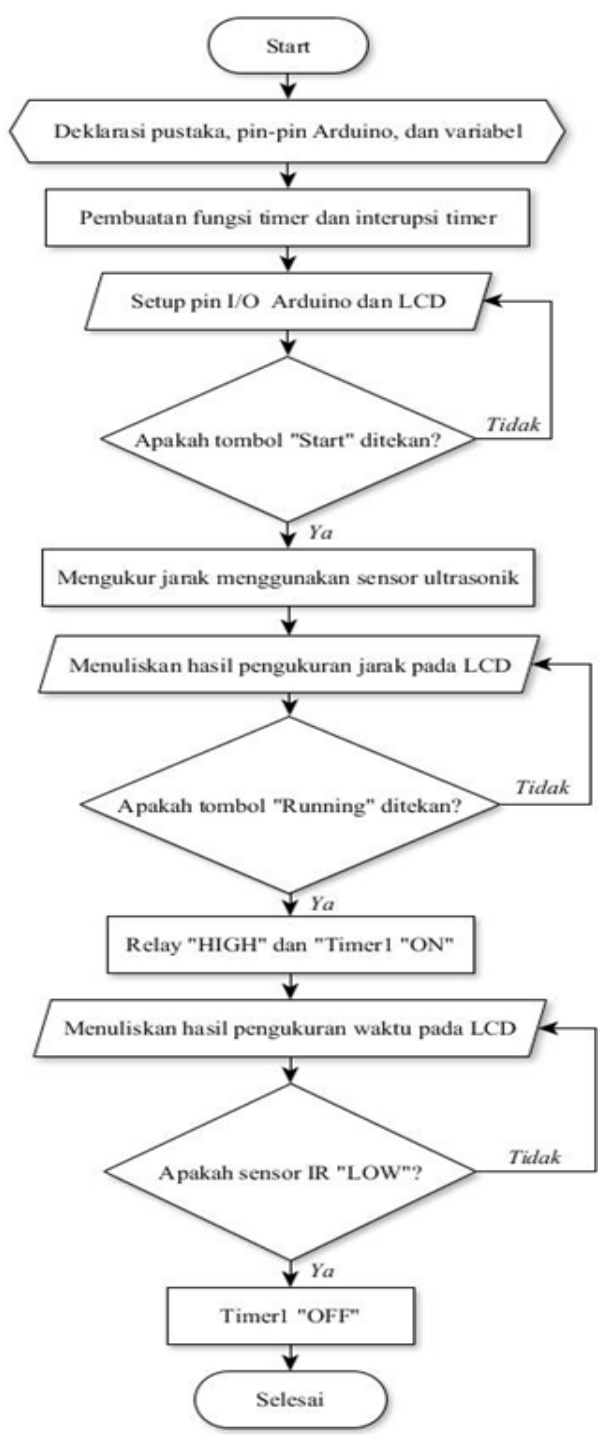

Gambar 3. Flowchart perangkat lunak

\section{HASIL PENGUJIAN}

Rancang bangun alat peraga fisika dalam kasus gerak jatuh bebas yang dikembangkan pada penelitian ini dapat 
digunakan secara efektif untuk melakukan analisis terhadap konsep gerak jatuh bebas. Hasil desain alat peraga gerak jatuh bebas ditunjukkan pada Gambar 4. Alat peraga yang dikembangkan ini bersifat portable dan mudah dalam pengoperasian ketika digunakan untuk memvisualisasikan konsep-konsep gerak jatuh bebas. Alat peraga ini juga dapat digunakan untuk kegiatan praktikum dalam mengukur percepatan gravitasi bumi.

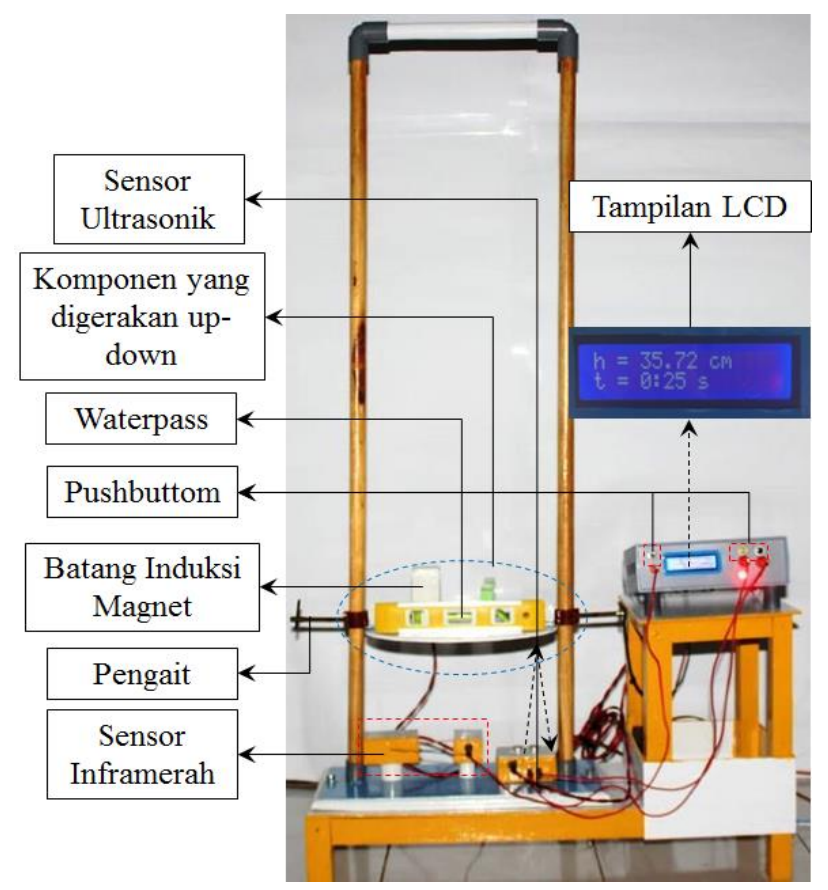

Gambar 4. Hasil rancang bangun alat peraga berbasis Arduino

Prinsip kerja alat peraga yang dikembangkan ketika digunakan untuk melakukan pengukuran terdiri dari beberapa tahap yaitu (1) menentukan tempat kedudukan benda yang akan mengalami gerak jatuh bebas, (2) mengukur ketinggian benda menggunakan sensor ultrasonik yang dikendalikan melalui tombol push button, (3) mengaktifkan induksi magnet dan menempatkan benda pada batang magnet, (4) menjatuhkan benda dengan mengendalikan kumparan yang dikendalikan melalui aktuator, (5) mengukur waktu tempuh benda menggunakan timer1 Arduino yang dikendalikan melalui trigger sensor inframerah, dan (6) hasil pengukuran ditampilkan pada LCD berupa ketinggian benda dan waktu tempuh.

Alat peraga yang telah dikembangkan mampu menampilkan hasil pengukuran ketinggian dan waktu tempuh benda melalui LCD seperti ditunjukkan pada Gambar 5. LCD yang digunakan dalam desain alat peraga ini adalah LCD karakter $16 \times 2$ yang terdiri dari 16 kolom dan 2 baris. Perancangan LCD di-interface-kan dengan Arduino melalui pin digital 2 sampai 7 seperti ditunjukkan pada Gambar 2. Pengiriman data dari Arduino ke LCD dilakukan melalui pin data D4 sampai D8, sedangkan untuk mengatur dan mengendalikan tampilan hasil pengukuran pada LCD dilakukan melalui pin RS dan EN pada LCD.
Sensor inframerah digunakan sebagai detektor gerak benda dalam rancang bangun alat peraga ini. Modul sensor inframerah terdiri dari dua bagian yaitu transmitter dengan komponen utama adalah LED inframerah dan receiver dengan komponen utama berupa fototransistor. Modul transmitter berfungsi untuk memancarkan cahaya inframerah sedangkan receiver berfungsi untuk menangkap cahaya inframerah menggunakan fototransistor. Ada tidaknya cahaya inframerah yang diterima oleh fototransistor akan menentukan output sensor inframerah. Output dari sensor inframerah di-interface-kan dengan pin digital 8 seperti ditunjukkan pada Gambar 2, sedangkan hasil desain modul sensor inframerah yang digunakan dalam rancang bangun alat peraga ini ditunjukkan pada Gambar 5.

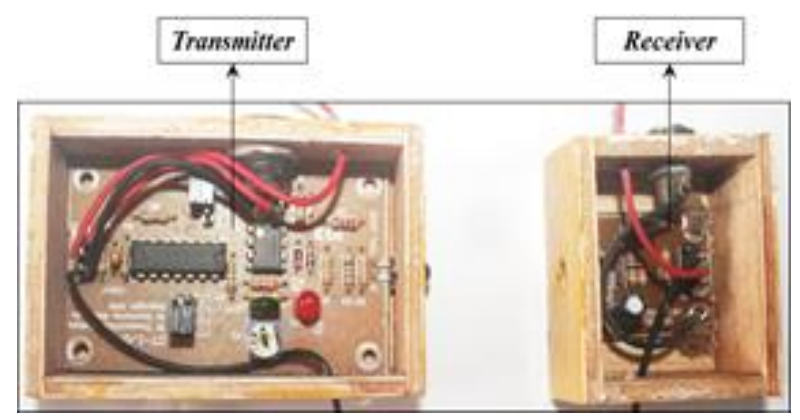

Gambar 5. Modul sensor inframerah

Prinsip kerja sensor inframerah dalam rancang bangun alat peraga ini yaitu LED memancarkan cahaya inframerah ke fototransistor sehingga menyebabkan output fototransistor dalam keadaan " $H I G H$ ". Apabila sebuah benda berada diantara LED dan fototransistor sehingga menghalangi cahaya inframerah untuk sampai ke fototransitor maka output fototransitor akan menjadi " $L O W$ '. Perubahan keadaan output fototransistor ini dimanfaatkan sebagai sinyal trigger untuk mengendalikan cacahan waktu yang dilakukan oleh fitur timer1 pada Arduino. Cara kerja untuk mencacah waktu yang diperlukan benda ketika jatuh bebas dalam alat peraga ini adalah ketika benda mulai terlepas dari batang magnet yang dikendalikan menggunakan tombol push button maka timer 1 akan " $O N$ " dan mencacah waktu selama benda jatuh. Ketika benda yang jatuh tersebut melewati sensor inframerah maka akan terjadi perubahan output pada fototransistor yang diberikan ke Arduino untuk menghentikan cacahan waktu dengan membuat timer1 pada Arduino menjadi " $O F F$ ". Pencacahan waktu dalam alat peraga ini sama seperti stopwatch otomatis yang dikendalikan menggunakan Arduino melalui tombol push button dan sensor inframerah.

Sensor ultrasonik digunakan sebagai perangkat elektronik untuk mengukur jarak/ ketinggian benda. Sensor ultrasonik yang digunakan dalam rancang bangun alat peraga ini adalah sensor ultrasonik tipe HY-SRF05. Sensor ultrasonik ini menghasilkan gelombang dengan frekuensi $40 \mathrm{kHz}$ (dalam daerah gelombang utrasonik) dan mampu mengukur jarak dari $3 \mathrm{~cm}$ sampai $400 \mathrm{~cm}$. Catu daya yang diperlukan agar sensor ini bekerja adalah 5 VDC dan beban arus yang dibutuhkan adalah $30 \mathrm{~mA}$ sampai $50 \mathrm{~mA}$. 
Gelombang ultrasonik yang dipancarkan merambat dengan laju $340 \mathrm{~m} / \mathrm{s}$. Lamannya waktu yang diperlukan sebanding dengan dua kali jarak sensor dengan objek karena gelombang ultrasonik dipancarkan oleh transmitter kemudian dipantulkan oleh objek yang akan diukur jaraknya lalu ditangkap oleh receiver.

Sensor ultrasonik HY-SRF05 memiliki 4 pin untuk interfacing yaitu pin Trigger dan Echo yang akan diinterface-kan dengan pin-pin Arduino, sedangkan pin VCC dan Ground di-interface-kan dengan catu daya seperti yang tampak dalam rangkaian perangkat keras pada Gambar 2 . Rancang bangun alat peraga ini menggunakan mode Trigger dan Echo terpisah untuk mengakses input dan output yang akan dilakukan oleh Arduino. Pin Trigger dan Echo sebagai pin input/ output untuk mengendalikan waktu yang diperlukan gelombang ultrasonik untuk merambat dari transmitter sampai receiver setelah dipantulkan oleh objek yang akan diukur jaraknya. Sensor ultrasonik yang digunakan dalam rancang bangun alat peraga ini telah terkalibrasi terhadap mistar dalam mengukur jarak. Proses kalibrasi sensor ultrasonik pada penelitian ini ditunjukkan pada Gambar 6.

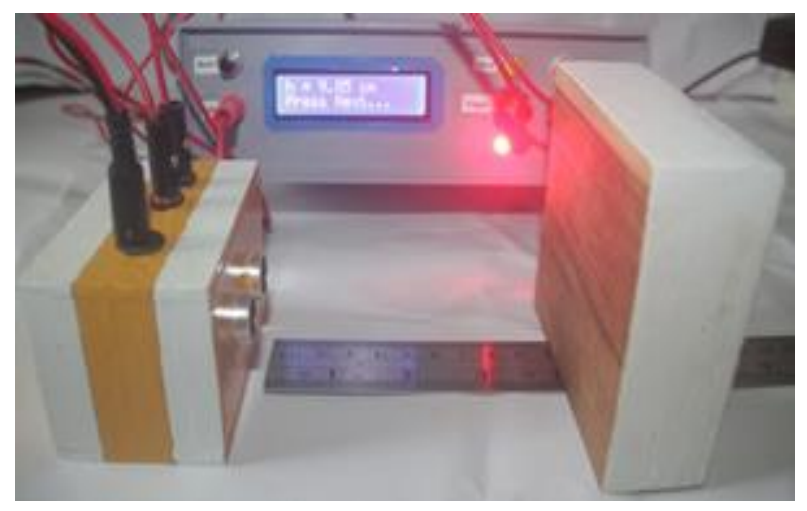

Gambar 6. Proses kalibrasi sensor ultrasonik

Kalibrasi sensor utrasonik merupakan suatu proses untuk menjadikan sensor ultrasonik agar memiliki hasil pengukuran jarak yang sama dengan alat ukur panjang seperti mistar yang biasa digunakan untuk mengukur jarak. Proses kalibrasi dilakukan dengan membandingkan jarak yang diukur menggunakan sensor ultrasonik dan jarak yang diperoleh mistar. Hasil kalibrasi jarak sensor ultrasonik terhadap mistar ditunjukkan pada Gambar 7. Hasil kalibrasi yang diperoleh menunjukkan perbandingan jarak sensor ultrasonik dan mistar adalah linear dengan persamaan linearitasnya adalah $y=1,01596 x-1,35378$. Persamaan ini memperlihatkan bahwa variabel $x$ merupakan jarak yang diukur menggunakan sensor ultrasonik dan $y$ merupakan jarak yang diukur menggunakan mistar. Persamaan linearitas ini yang digunakan untuk menghitung ketinggian benda dalam proses pengukuran.

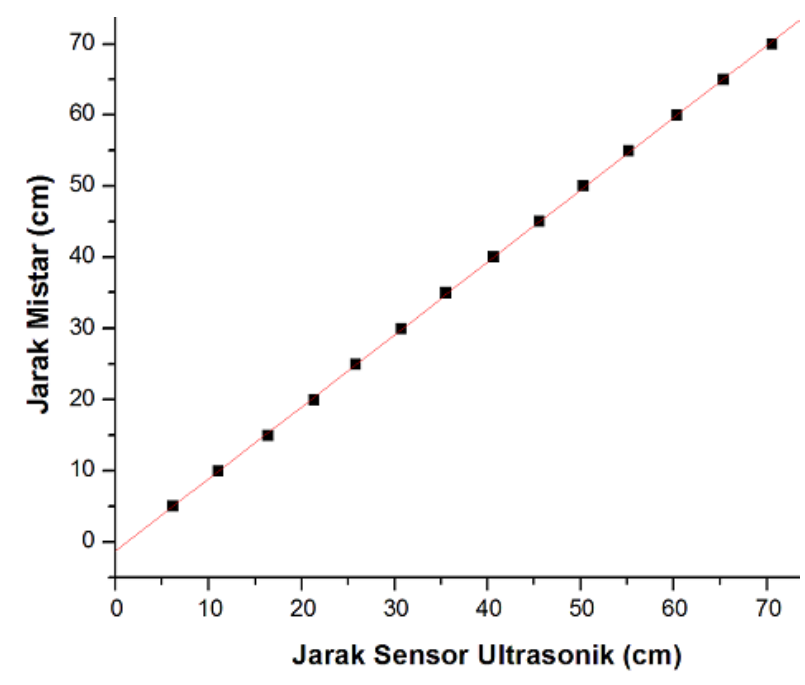

Gambar 7. Grafik kalibrasi sensor ultrasonik terhadap mistar

Rancang bangun sistem aktuator diperlukan dalam alat peraga ini untuk mengendalikan arus pada kumparan. Arus yang dialirkan pada kumparan menggunakan tegangan 12 VDC sedangkan output tegangan yang diberikan oleh Arduino adalah 5 VDC pada kondisi " $H I G H$ " sehingga Arduino tidak dapat mengendalikan arus pada kumparan secara langsung. Sistem aktuator dalam rancang bangun alat peraga ini terdiri dari relay $12 \mathrm{~V}$, transistor BD139, resistor, diode 1N4007, dan LED. Rangkaian perangkat keras sistem aktuator seperti ditunjukkan pada Gambar 2, sedangkan hasil desain sistem aktuator ditunjukkan pada Gambar 8 .

Sistem aktuator berfungsi untuk menerjemahkan output digital ke output analog. Ketika sinyal " $H I G H$ " dikeluarkan oleh pin Arduino maka transistor akan terbuka dan ada perbedaan tegangan sehingga arus akan mengalir pada kumparan relay sehingga merubah output relay. Perubahan output relay akan memutuskan arus yang mengalir pada kumparan sehingga menghilangkan medan magnet pada batang induksi dan benda akan jatuh bebas. Desain sistem aktuator menggunakan mode Normally Close (NC) yaitu dalam kondisi "idle" arus mengalir pada kumparan, sedangkan ketika terjadi perubahan logika yang diberikan dari Arduino maka tidak ada arus yang mengalir pada kumparan.

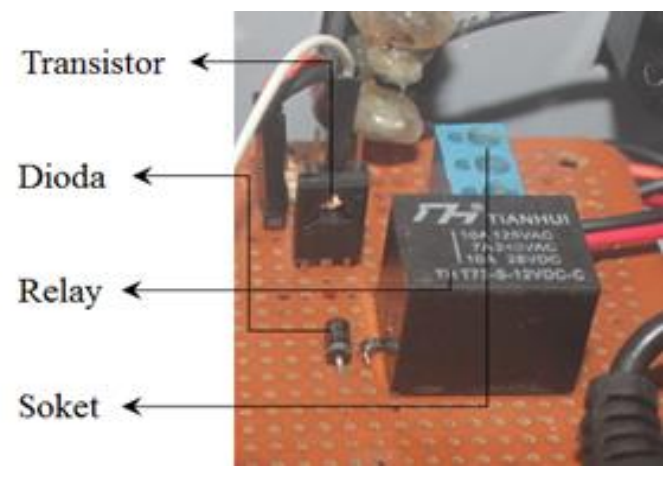

Gambar 8. Hasil desain sistem aktuator 
Desain perangkat lunak berfungsi untuk mengatur kinerja alat peraga agar bekerja berdasarkan alur maupun logika tertentu. Hasil desain perangkat keras akan bekerja berdasarkan alur perangkar lunak yang didesain dan ditanamkan pada Arduino. Hasil desain perangkat lunak ditunjukkan pada Gambar 9. Desian perangkat lunak terdiri dari 6 bagian utama, antara lain: fungsi timer, interrupt timer overflow, mengukur jarak, kendali aktuator, mengukur waktu, dan menuliskan hasil pengukuran pada LCD. Desain perangkat lunak juga terdiri dari tiga logika pengambilan keputusan seperti ditunjukkan pada Gambar 3. Logika ini dikendalikan melalui input dari tombol push button dan sensor inframerah. Penggunaan logika dalam pengambilan keputusan dalam rancang bangun alat peraga ini bertujuan untuk mengendalikan pengoperasian alat peraga dalam mengukur ketinggian benda dan waktu tempuh.

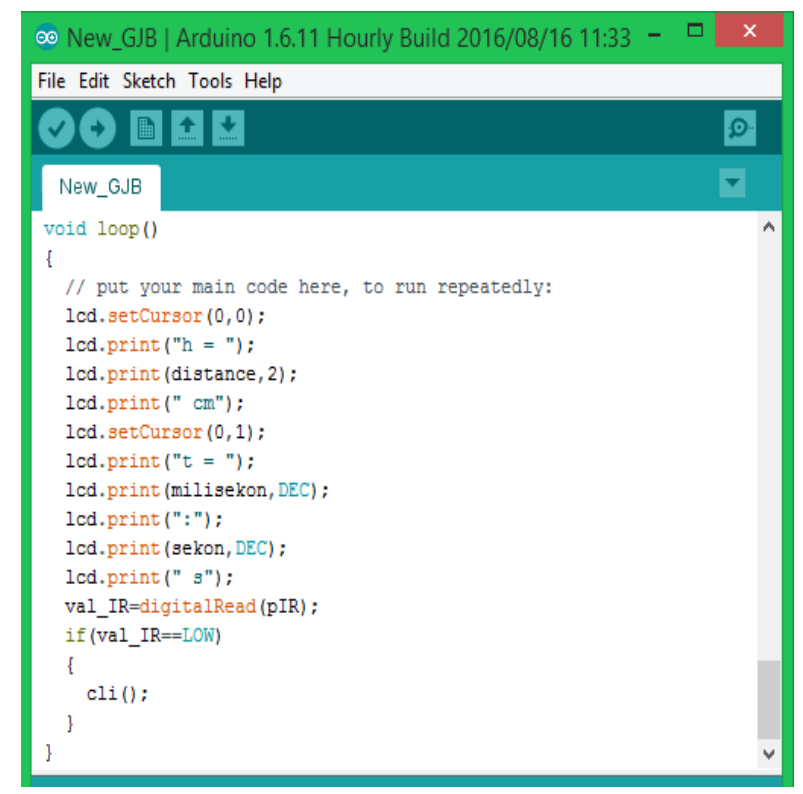

Gambar 9. Hasil desain perangkat lunak

Pengujian kinerja alat peraga dilakukan untuk mengetahui kemampuan alat peraga dalam mengukur ketinggian benda dan waktu tempuh. Hasil pengukuran yang diperoleh digunakan untuk menganalisis konsepkonsep pada gerak jatuh bebas. Variabel-variabel fisis yang dapat dihitung dengan menggunakan hasil pengukuran alat peraga yang dibangun yaitu percepatan gravitasi bumi dan kelajuan benda. Hasil analisis yang diperoleh dari pengukuran menggunakan alat peraga diperoleh percepatan gravitasi bumi $(g)$ menggunakan alat peraga ini adalah $10,2 \mathrm{~m} / \mathrm{s}^{2}$. Hasil pengukuran ini menunjukkan kinerja alat peraga yang baik jika dibandingkan dengan nilai teoritik percepatan gravitasi bumi yaitu sebesar $9,8 \mathrm{~m} / \mathrm{s}^{2}$. Perbedaan hasil yang diperoleh disebabkan oleh pengukuran ketinggian menggunakan sensor ultrasonik yang tidak konsisten pada ketinggian tertentu seperti ditunjukkan pada hasil kalibrasi pada Gambar 7.
Hasil pengukuran ketinggian benda $(h)$ dan waktu tempuh $(t)$ bola serta hasil perhitungan percepatan gravitasi bumi $(g)$ dan kelajuan benda $(v)$ dapat dianalisis untuk menjelaskan konsep-konsep dalam gerak jatuh bebas. Pengaruh waktu tempuh terhadap kelajuan benda dalam gerak jatuh yang diperoleh dalam hasil pengukuran ditunjukkan pada analisis pada Gambar 10. Hasil analisis grafik memperlihatkan terdapat hubungan yang linear antara kelajuan benda dan waktu tempuh. Hasil ini sesuai dengan konsep teoritik yang diperlihatkan dalam persamaan $v=g t$ dimana $v$ sebanding dengan $t$ secara linear.

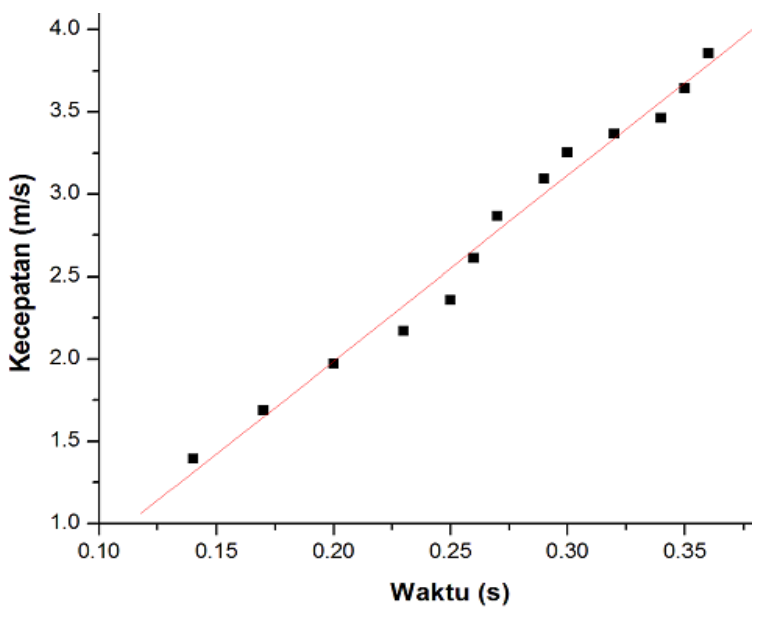

Gambar 10. Grafik v-t hasil pengukuran

Hasil pengukuran ketinggian benda dan waktu tempuh dianalisis hubungannya dalam grafik seperti ditunjukkan pada Gambar 11. Grafik ini memperlihatkan hubungan kuadratik antara ketinggian benda dan waktu tempuh. Hasil ini sesuai dengan konsep teoritik seperti yang dinyatakan dalam persamaan $h=1 / 2 g t^{2}$ yang mana $h$ sebanding dengan kuadrat dari $t$. Hasil pengukuran ketinggian benda dan laju benda dianalisis hubungannya dalam grafik seperti ditunjukkan pada Gambar 12. Grafik ini memperlihatkan hubungan kuadratik antara kelajuan dan ketinggian benda. Hasil ini sesuai dengan konsep teoritik seperti yang dinyatakan dalam persamaan $v=\sqrt{2 g h}$ yang mana $v$ sebanding dengan akar kuadrat dari $h$.

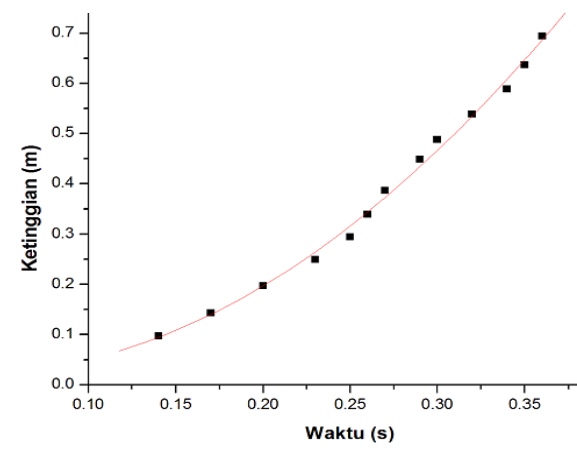

Gambar 11. Grafik h-t hasil pengukuran 


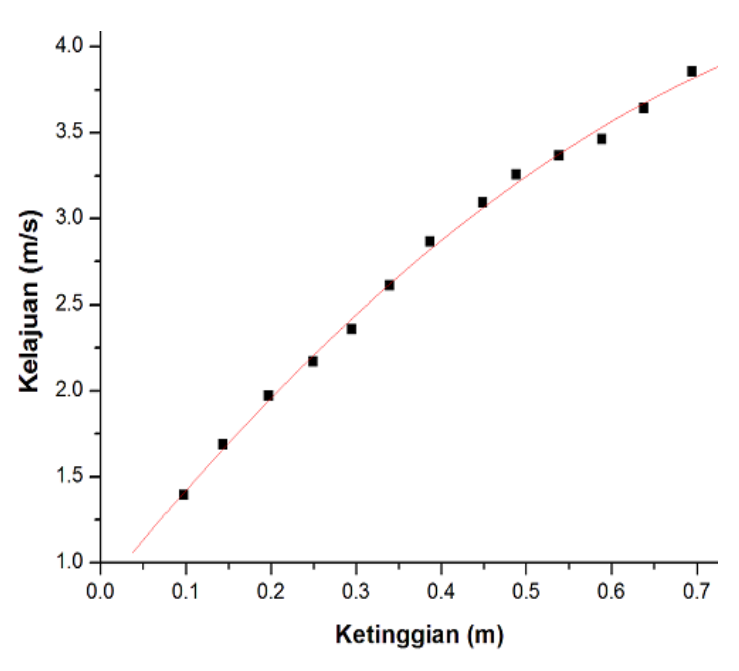

Gambar 12. Grafik v-h hasil pengukuran

\section{KESIMPULAN}

Alat peraga gerak jatuh bebas telah dikembangkan menggunakan perangkat keras seperti sensor ultasonik, sensor inframerah, tombol push button, Arduino, LCD, LED, dan sistem aktuator, sedangkan perangkat lunak menggunakan bahasa C\#. Pengujian kinerja komponen elektronik yang digunakan mampu mengukur dengan tepat besaran fisis yang diukur. Sensor ultrasonik digunakan untuk mengukur ketinggian benda, sedangkan waktu tempuh benda diukur menggunakan timer1 Arduino yang dikendalikan melalui input tombol push button dan sensor inframerah. Pengujian alat peraga dalam membuktikan konsep-konsep gerak jatuh bebas memperlihatkan hasil pengukuran yang diperoleh sesuai dengan konsep-konsep teoritik baik itu hubungan $v-t, h$ - $t$, dan $v$ - $h$. Alat peraga yang dikembangkan juga mampu digunakan untuk mengukur percepatan gravitasi bumi $(g)$ dengan rata-rata nilai $g$ yang diperoleh yaitu sebesar $10,2 \mathrm{~m} / \mathrm{s}^{2}$.

\section{DAFTAR PUSTAKA}

[1] Popescu, A., dan Morgan, J. 2007. Teaching Information Evaluation and Critical Thinking in Physics Classes. The Physics Teacher, 45: 507-510.

[2] Daryanto. 2013. Media Pembelajaran (2 $2^{\text {nd }}$ ed.). Yogyakarta: Gava Media.

[3] Sudjana, N., 2011. Dasar-Dasar Proses Belajar Mengajar ( $2^{\text {nd }}$ ed.). Bandung: Sinar Baru Algensindo.

[4] Susilana, R., dan Riyana, C., 2007. Media Pembelajaran. Bandung: CV Wacana Prima.

[5] Arsyad, R., 2009. Media Pembelajaran (1 ${ }^{\text {st }}$ ed). Jakarta: PT Rajagrafindo Persada.

[6] Preliana, E., 2015. Pengembangan Alat Peraga Sains Fisika Berbasis Lingkungan Untuk Materi Listrik Statis Pada Siswa Kelas IX SMP Negeri 3 Pleret. JRKPF UAD. 2(1): 6-11.

[7] Fitriani, N., 2013. Pengembangan Alat Peraga Sains Fisika Dengan Memanfaatkan Sampah Anorganik Materi Kelistrikan dan Kemagnetan Pada Siswa SMP/MTS. Skripsi. Jurusan Pendidikan Fisika, Fakultas Sains dan Tekonologi, Universitas Islam Negeri Sunan Kalijaga, Yogyakarta.

[8] Wicaksono, A., dan Rifai, I., 2013. Pembuatan Alat Peraga Pendidikan Fisika Sub Materi Gerak Jatuh Bebas Berbasis Mikrokontroler Arduino Uno. Seminar Nasional Teknologi Terapan. Yogyakarta, Indonesia. Hal. 440-447.

[9] Susilawati., dan Aryanto, D., 2013. Penerapan Alat Praktikum Viskometer Terhadap Pencapaian Kinerja Mahasiswa Calon Guru Fisika. Seminar Nasional $2^{\text {nd }}$ Lontar Physics Forum. ISBN: 978-602-8047-80-7. 